\title{
Vertical Growth Phase
}

National Cancer Institute

\section{Source}

National Cancer Institute. Vertical Growth Phase. NCI Thesaurus. Code C35898.

A morphologic architectural pattern in which the tumor cells spread vertically. 